Т. І. Сябрук]. - К. : ДВНЗ «Університет менеджменту освіти» НАПН України, 2018. - 166 с.

2. Курицина Г.В. Формы и методы контроля качества дистанционного обучения студентов ВУЗа // Международный журнал экспериментального образования. - 2014. - № 8-3. - С. 17-21

3. Водоп'ян Н.І. Організація оцінювання навчальних досягнень учнів в умовах дистанційного навчання засобами Microsoft Forms: Використання системи комп'ютерного моделювання в умовах дистанційного навчання: збірник матеріалів за заг. ред. С.Г. Литвинової, О.М. Соколюк. Київ: ФОП Ямчинський О.В. 2020. 195 с.

DOI https://doi.org/10.30525/978-9934-588-80-8-2.4

\title{
ЗАКОНОМІРНОСТІ І ПРИНЦИПИ КОНЦЕПЦІЇ РОЗВИТКУ ПРОФЕСІЙНО-ПЕДАГОГІЧНОЇ КОМПЕТЕНТНОСТІ ВИКЛАДАЧІВ ТЕХНІЧНИХ ЗАКЛАДІВ ВИЩОЇ ОСВІТИ
}

\author{
Горохівська Т. М. \\ кандидат педагогічних наук, \\ доиент кафедри педагогіки та інновачійної освіти \\ Національний університет «Львівська політехніка» \\ м. Львів, Україна
}

Як прояв сучасної філософії освіти методологічну основу української освіти становить гуманістична парадигма, метою якої $є$ виховання духовно багатої, національно свідомої особистості, суб'єкта повноцінної професійної діяльності. Через це в умовах реформування вищої вітчизняної школи помітної актуальності набуває проблема розвитку професійно-педагогічної компетентності викладачів технічних ЗВО. Реалізація цієї проблеми передбачає обгрунтування концепції розвитку професійно-педагогічної компетентності викладачів технічних ЗВО, важливими складовими компонентами якої є закономірності і принципи, розгляду яких і присвячена ця робота.

Важливою характеристикою будь-якого процесу, який відбувається в суспільстві (у тому числі і педагогічного) є закономірна логіка. Саме вона визначає напрям руху процесу, що залежить від вищих орієнтирів, на досягнення яких спрямовані усі зміни, які відбуваються у межах цього процесу. Закономірна логіка обумовлює закономірний невипадковий характер змін, що відбуваються в умовах процесу, 
виявляє тенденцію їхнього розвитку, яка забезпечує максимальне поетапне залучення суб'єктів навчання в педагогічний процес. Тому традиційно педагогічні закономірності розглядаються як «об'єктивні, стійкі і суттєві зв'язки в освітньому процесі, що зумовлюють його ефективність: спрямованість на розв'язання завдань всебічного i гармонійного розвитку особистості; зміст освіти закономірно залежить від завдань, які відображають потреби суспільства; активно-діяльнісний характер навчання; взаємозалежність навчально-пізнавальної активності і рівня мотиваційної сфери» [1, с. 131].

Ми вважаємо, що для відображення об'єктивної педагогічної реальності у вигляді процесу розвитку професійно-педагогічної компетентності викладачів фахових дисциплін доцільним $є$ виділення саме закономірностей, а не законів, оскільки закономірність, представляючи собою результат сукупної дії багатьох законів, відображає чимало зв’язків і відносин, тоді як закон однозначно формулює певний зв'язок, відношення. При цьому науковцями визначаються ознаки, відповідно до яких зв'язки можна віднести до закономірних: причиннонаслідковий характер зв'язку (об'єктивність, незалежність зв'язку від бажань, настроїв); загальність (прояви у професійно-педагогічній діяльності будь-якого педагога); повторюваність (здатність зв'язків відтворюватися у аналогічних ситуаціях). Таким чином, в нашому дослідженні педагогічні закономірності становлять зв'язки між педагогічними явищами у освітньому процесі, яким притаманний причино-наслідковий характер, об'єктивно існуючі критерії загальності і повторюваності.

Науковці до закономірностей професійного розвитку відносять: особистісне самовизначення має передувати професійному, у ньому закладаються вимоги до професії; після первинного вибору професії подальший професійний розвиток залежить від індивідуальнопсихологічних особливостей, відбувається диференціація професійних інтересів; подальше професійне самовизначення починає впливати на особистісне і людина починає сприймати життя керуючись професією; формується професійний тип особистості; професія стає засобом самовираження особистості, що відповідає професійній зрілості 3 одного боку і створює передумови для професійних деформацій 3 іншого [3].

В якості закономірностей, які розкривають сутність процесу розвитку професійно-педагогічної компетентності викладачів технічних закладів вищої освіти ми визначаємо наступні:

- сильна мотивація професійно-педагогічних досягнень нівелює недостатність здібностей; 
- спершу особистісний розвиток стимулює розвиток професійнопедагогічної компетентності, потім навпаки, професійно-педагогічна компетентність стимулює особистісний розвиток викладача, при цьому обидва ці процеси взаємопов'язані у єдиний особистісно-професійний розвиток;

- розвиток професійно-педагогічної компетентності відбувається гетерохронно, нерівномірно, відбувається за допомогою подолання протиріч, які постійно виникають;

- розвиток професійно-педагогічної компетентності викладача технічного закладу вищої освіти $\epsilon$ можливим, якщо відповідає характеру самовдосконалення і самореалізації;

- мотивація до неперервного особистісно-професійного самовдосконалення виступає важливим фактором розвитку професійнопедагогічної компетентності і вимагає зовнішніх умов - акмеологічної підтримки і акмеологічного середовища на всіх етапах неперервної післядипломної професійної освіти;

- розвиток професійно-педагогічної компетентності викладачів технічних закладів вищої освіти пов'язаний $з$ появою індивідуального стилю професійно-педагогічної діяльності та єднання 3 предметом праці;

- динаміка розвитку професійно-педагогічної компетентності викладачів фахових дисциплін полягає у переході від репродуктивної, поелементної діяльності до системної, рефлексивної, інноваційної творчої.

Керуючись тезою про те, що закономірність - це реальність, дійсність, а принцип - логічна експлікація належного, потрібного, певний механізм досягнення відповідного, концепція розвитку професійно-педагогічної компетентності викладачів технічних закладів вищої освіти спирається на систему педагогічних принципів - вихідних положень, керівних ідей i основних вимог, що випливають 3 встановлених педагогічною наукою закономірностей та реалізуються у цілях, змісті, педагогічних технологіях, професійно-педагогічній діяльності викладачів. Прикладом визначення принципів, на яких грунтується особистісно-орієнтований професійний розвиток, є позиція С. Сисоєвої, відповідно до якої означаються наступні: самоцінності індивідуума; визначення слухача як активного суб'єкта пізнання; соціалізації; урахування суб'єктного досвіду; орієнтації навчання на саморозвиток, самоосвіту; врахування індивідуальних психофізіологічних особливостей; розвитку комунікативних здібностей [4, с. 21]. В. Іванова до універсальних принципів освітнього середовища підготовки спеціалістів зараховує: принцип динамічності - об'єкт дослідження володіє внутрішніми ресурсами для саморозвитку i 
проявляється тільки в динаміці; принцип прогностичності дослідження перспектив розвитку об'єкта шляхом прогнозування евентуального стану об'єкта; принцип детермінізму - спрямованість особистості на самостійність, відповідність, приналежність до обраної професії; принцип суб'єктної діяльності - характеризує психологічні механізми реального, фактичного досягнення «оптимуму» у особистісно-професійному розвитку [2, с. 160-164].

Зважаючи на те, що процес розвитку професійно-педагогічної компетентності викладачів відбувається в умовах навчального процесу курсів підвищення кваліфікації, вихідними дидактичними положеннями, які окреслюють перебіг об'єктивних законів і закономірностей процесу навчання i скеровують його направленість на розвиток особистості (у нашому дослідженні - це розвиток професійно-педагогічної компетентності) $є$ принципи навчання. Саме принципи навчання відповідають за теоретичні підходи до побудови процесу навчання, розкривають установки, 3 якими викладачі підходять до його організації i передбачають спрямованість навчального процесу на професійний саморозвиток 3 пошуками можливостей його вдосконалення.

3 метою забезпечення результативності розвитку професійнопедагогічної компетентності викладачів фахових дисциплін технічних закладів вищої освіти означимо принципи, які відображають ключову ідею професійної підготовки науково-педагогічних працівників в контексті досліджуваної проблеми: науковості і фундаментальності, системності і послідовності, функціональної цілісності і детермінізму, неперервності i наступності, варіативності i діалогічності, проблемності і прогностичності, індивідуалізації і суб'єктності, інтеграції і демократизації, професійної спрямованості.

Необхідно зазначити, що основними вимогами, якими ми керувались під час відбору принципів розвитку професійно-педагогічної компетентності - це їхня універсальність, важливість та імперативність, в той час як зміст означених принципів $є$ абстрактним відображенням закономірностей.

Таким чином, встановлені в ході дослідження закономірності i принципи спрямовані на вирішення низки методологічних завдань, а саме: дозволяють окреслити ключові внутрішні властивості професійно-педагогічної компетентності викладачів технічних закладів вищої освіти; надають можливість встановити взаємообумовлюючі фактори, які впливають на розвиток досліджуваної компетентності; встановлюють зв'язок теорії з практикою післядипломної педагогічної освіти викладачів технічних ЗВО. 


\title{
Література:
}

1. Гончаренко С.У. Український педагогічний словник / гол. ред. С. Головко. К.: Либідь, 1997. 376 с.

2. Иванова В.И. Акмеологическая концепция формирования образовательной среды подготовки специалистов : дис. ... д-ра пед. наук : 19.00.13. Москва, 2009. 662 с.

3. Маркова А.К. Психология профессионализма. М.: Междунар. гуманит. фонд «Знание», 1996. 308 с.

4. Сисоєва С. Професійна підготовка в контексті особистісноорієнтованої парадигми освіти. Педагог професійної школи : зб. наук. пр. / упоряд.: Н.Г. Ничкало, О.І. Щербак. К.: Науковий світ, 2003. Вип. 5. С. 20-24.

DOI https://doi.org/10.30525/978-9934-588-80-8-2.5

\section{РОЗВИТОК ІНШОМОВНОЇ КОМУНІКАТИВНОЇ КОМПЕТЕНЦІЇ КУРСАНТІВ 3 ВИКОРИСТАННЯМ ТЕХНОЛОГІЙ ДИСТАНЦІЙНОГО НАВЧАННЯ}

\author{
Дроб Н. Ч. \\ старший науковий співробітник \\ навчально-наукового центру мовної підготовки \\ Харківський начіональний університет \\ Повітряних Сил імені Івана Кожедуба
}

Федорчук А. С.

науковий співробітник навчально-наукового ценнтру мовної підготовки

Харківський національний університет

Повітряних Сил імені Івана Кожедуба

м. Харків, Украӥна

Модернізація системи вищої військової освіти та умови сьогодення передбачають активний розвиток використання дистанційної освіти форми навчання, під час якого взаємодія викладача та того, хто навчається - курсанта, а також курсантів між собою здійснюється на відстані та відображає всі притаманні навчальному процесу компоненти (цілі, зміст, методи, організаційні форми, засоби навчання), що реалізуються специфічними засобами мультимедійних технологій, 